\section{LA VIVIENDA: CRÓNICA DE UNA POBREZA ANUNCIADA}

Max Aguirre González ${ }^{1}$

La vivienda, sin duda, es una realidad cultural de enorme complejidad y riqueza. Es de aquellos fenómenos humanos que pone en evidencia la profundidad de las relaciones y vínculos que, tal vez, las personas no realizan desde ninguna otra de sus actividades.

Esta apreciación es la que se exhibe en este número de revista INVI. La publicación consta de siete artículos que abordan la vivienda, cada uno de ellos, respectivamente, desde los siguientes enfoques: las periferias interiores creadas a partir del crecimiento de la ciudad en torno a barrios foco

1 Chile. Doctor Arquitecto, Universidad Politécnica de Madrid. Director del Instituto de Historia y Patrimonio, Facultad de Arquitectura y Urbanismo, Universidad de Chile.

\section{HOUSING: CHRONICLE OF A POVERTY FORETOLD}

\author{
Max Aguirre Gonzalez
}

There is no doubt that housing is a highly complex and rich cultural reality. It is a human phenomenon that reveals the depth of relationships and bonds generated by housing in a manner that people, perhaps, cannot replicate in any other activity.

Such an approach is offered in this issue of Revista INVI. This edition comprises seven papers that address housing from different perspectives: inner peripheries generated from the growth of the city centering on neighborhoods that act as focal points of vulnerability; territorial analysis of public policies 1 Chile. PhD. In Architecture, Technical University of Madrid. Director,
Institute of History and Heritage, Faculty of Architecture and Urban
Planning at the University of Chile. Email: maxaguirre@uchilefau.cl 
de vulnerabilidad, el análisis territorial de la política pública de regeneración barrial y la mejora de resultados escolares, las tácticas de asentamientos espontáneos en los márgenes de la ciudad de Sevilla, la vivienda en el contexto del fracaso del modelo inmobiliario español, la dinámica habitacional en Chillán observada en un periodo de más de un siglo, las azudas de Larmahue y su relación con el territorio y paisaje agrario y, por último, la estigmatización barrial y sus variados efectos sociales.

Cada uno de estos artículos constituye un mundo que por sí solo nos retrata las vicisitudes de la vivienda, pero sobre todo de sus habitantes. Impresiona captar la unidad de los temas en torno a un mismo grupo social, vulnerable, empobrecido, marginado, estigmatizado. Una realidad a todas luces indigna, injusta e inaceptable. ¿Qué ocurre? ¿Cómo es posible que no se logre superar la pobreza que sostiene la realidad de la vivienda espontánea, informal o insuficiente?

Paula Kapstein López y Edith Aranda Dioses escriben Las periferias interiores de Lima: localización e identificación de los barrios focos de vulnerabilidad. El caso de San Cosme. Allí exploran y describen el fenómeno de "las periferias interiores", un hecho que se configura a partir del crecimiento explosivo de Lima en la década de 1930, que se acentuó entre 1940 y 1981 atrayendo un volumen de población en un breve periodo que desbordó, sin orden ni planificación alguna, los límites que contenía la for neighborhood regeneration and the improvement of scholastic achievement at school; the tactics of spontaneous settlements on the borders of Seville; housing within the context of the failure of the Spanish real estate model; housing dynamics in Chillan, observed over a period of more than a hundred years; the waterwheels of Larmahue and their relationship with the territory and the rural landscape; and, lastly, neighborhood stigmatization and its different social consequences.

Each of these papers portrays a world that on its own tells us of the ups and downs of housing, but above all its inhabitants. It is striking to grasp the unity of the issues surrounding a given vulnerable, impoverished, marginalized and stigmatized social group. Such a reality is clearly undeserving, unfair and unacceptable. What is it happening? How is it possible to fail at overcoming the poverty that supports the reality behind spontaneous, informal and substandard housing?

Paula Kapstein Lopez and Edith Aranda Dioses are the co-authors of the contribution entitled "The Inner Peripheries of Lima: Location and Identification of Neighborhoods that Act as Focal Points of Vulnerability. The Case of San Cosme". In this paper, they explore and describe the phenomenon of "inner peripheries", an event resulting from the explosive growth experienced by Lima during the 1930s which gained in intensity over the 1940-1981 period. 
ciudad hasta entonces. Tal extralimitación fue dejando atrás y atrapados, ciertos bolsones de precariedad rodeados de nuevos barrios "entre áreas de distinto uso y categoría”, que acentuaron la marginalidad sumándole el aislamiento. El trabajo localiza y delimita "el sistema de periferias interiores" de Lima, que rodea el centro histórico de la ciudad, constituyendo una especie de red de residuos no deseados que ofrecen la paradoja de estar "consolidados" porque cuentan, entre otros, con servicios básicos como pavimentación e iluminación, pero siguen siendo "vulnerables" porque, por ejemplo, son focos de delincuencia, inseguridad y falta de accesibilidad. El estudio de Kapstein y Aranda descubre una realidad y levanta una información que permitiría, si se quiere construir una estrategia de regeneración urbana, "aunar los esfuerzos que ya se están llevando a cabo puntualmente".

Fernando Campos Medina es autor del texto La escala geográfica de la exclusión en Santiago de Chile. Un análisis territorial de la politica de regeneración barrial y mejoramiento de resultados escolares, donde se propone describir "la fragmentación socio-espacial en el área metropolitana de Santiago, a partir de la escala barrial". Para ello, cruza la información obtenida del relevamiento de los territorios de implementación de dos políticas públicas: una, la regeneración de barrios para revertir el proceso de acelerada degradación urbana y otra, la intervención en escuelas con bajo rendimiento escolar para elevar los resultados de aprendizaje. La hipótesis
Such an event entailed a massive influx of population, which exceeded the then limits of the city without any regard for order or planning whatsoever. As a result, certain pockets of precariousness were forgotten and locked within new neighborhoods located "in areas of different use and category", which increased marginality in the addition to theirisolation. Thispaper localizes and defines the "system of inner peripheries" of Lima that surrounds the historical downtown of the city and configures a network of unwanted residues that is paradoxically "consolidated" due to the access to basic services such as pavement and lighting. However, these neighborhoods are still "vulnerable" as the result of being focal points of crime, insecurity and inaccessibility. The study conducted by Kapstein and Aranda reveals a new reality and provides information that may "pull together current efforts in this matter" in the case of pursuing a strategy for urban regeneration.

Fernando Campos-Medina, in his paper entitled "The Geographic Scale of Exclusion in Santiago, Chile, a Territorial Analysis of Public Policies on Neighborhood Regeneration and Improvement of School Achievement", describes the "socio-spatial fragmentation within the metropolitan area of Santiago from a neighborhood scale". The author collates information collected from the analysis of territories where two public policies have been set up: on the one hand, there is the regeneration of neighborhoods which is intended to reverse the 
que se maneja es que estas dos formas de intervención ponen en evidencia "una geografía de la exclusión" que manifiesta una condición estructural del territorio metropolitano, pero también continuas prácticas sociales tendientes a la relegación. Las causas serían: cierta incapacidad institucional de operar integradamente en el territorio y una situación social problemática, que ha excedido el nivel barrial y abarca grandes áreas de exclusión que sobrepasa la acción de la política pública existente. Acaba concluyendo que "sería de esperar que la intervención en barrios y escuelas reconociera un potencial de complementariedad tanto al nivel del diagnóstico como de la intervención".

María Prieto Peinado expone en su artículo Asentamientos espontáneos, tácticas en los márgenes de la ciudad de Sevilla, Los Perdigones, un caso de asentamiento informal en los alrededores del área ocupada por la Exposición Universal de 1992. Se propone probar que "a través del conocimiento de la cualidad de los procesos espaciales, en los asentamientos (...) (se puede establecer) ciertas claves, en la reformulación de la producción urbana y el habitar (...) (mediante) dispositivos adaptables a cualquier ámbito". La investigación de base apunta a los "entornos de cambio" del sistema Ciudad, allí donde se producen "transformaciones no controladas". Hace una revisión amplia de las ideas de autores como Lefebvre, Certeau, Foucault y LéviStrauss, entre otros, con las que crea un fondo contra el cual proyecta sus observaciones sobre el rapid urban degradation process and, on the other hand, there is the intervention in low performing schools, is intended to improve learning achievement. The hypothesis is that these two methods expose a "geography of exclusion" that in turn reveals both a structural condition within the metropolitan territory and repeated social practices that lead to relegation. Reasons for this include: a certain institutional incapacity to properly operate in a given territory and a problematic social situation that transcends the neighborhood level and covers large areas of exclusion that cannot be addressed by current public policies. This research concludes that "it is only to be expected that intervention on neighborhoods and schools identifies a potential of complementarity at diagnostic and intervention level".

The paper "Spontaneous Settlements, Tactics on the Borders of the City of Seville, Los Perdigones", written by Maria Prieto Peinado, exposes the case of an informal settlement located in the area around the site of the Seville Expo '92. This paper proves that "by understanding the quality of spatial processes (...) certain key issues (can be set up) in settlements to reformulate both urban production and the act of inhabiting (by means of) devices adapted to any type of context". The focus of this study is the "changing environments" of the City system, which is where "uncontrolled transformations" take place. This contribution also conducts a comprehensive review of the ideas proposed by authors such as Lefebvre, 
caso estudiado. Desde ahí extrae los "beneficios de la convivencia plural, de la existencia itinerante arraigada a su propio caminar, y el beneficio de valores desusados como el intercambio o la solidaridad", reflexión conclusiva que denomina con el cuestionable título: "la riqueza de la pobreza".

Carlos Jiménez Romera y Cristina Fernández Ramírez escriben Casas sin gente, gente sin casas: el fracaso del modelo inmobiliario español. Presentan una indagación muy informada y didáctica sobre las circunstancias de lo que fue desde diversos frentes de acción política, financiera y social, en algún momento, el modelo de un desarrollo exitoso que condujo al fracaso en el que el sector vivienda se ha llevado aparentemente la peor parte. Uno de los datos que da una idea de la magnitud de la debacle, indica que "el endeudamiento de las familias en relación a la renta bruta disponible pasó del 58\% al 103\% entre 1998 y 2005". El proceso de descomposición del sistema hecho visible por la morosidad, afectó primero a los promotores, luego a los restantes agentes inmobiliarios y finalmente a las familias. Sentencian y advierten los autores: "la base de una burbuja especulativa reside en la confianza ciega en la revalorización", que en este caso llevó a crear la contradictoria situación de contar con un enorme parque de viviendas disponibles en el mercado y, paralelamente, un número importante de familias que quieren adquirir una casa y no pueden por el excesivo costo de la deuda. La lección es sencilla: "la política de vivienda no
De Certeau and Foucault with the aim of elaborating a screen on which to project the observations on the issues under study. Such an exercise regains the "benefits of plural coexistence, its itinerant nature and the benefits of obsolete values such as exchange or solidarity", which serves as a conclusive reflection that bears the questionable name of "the richness of poverty".

Carlos Jimenez Romera and Cristina Fernandez Ramirez are the co-authors of "Houses without People, People without Houses: the Failure of the Spanish Real Estate Model". This paper offers thorough and didactic research on the circumstances of what were diverse political, financial and social policies, which at one time were a model for successful development and which brought about the failure of the housing sector which has apparently reached its worst state. Evidence that serves to give an idea of the scale of such collapse states that "the debt situation of families in relation to gross disposable income rose from 58 percent in 1998 to 103 percent in 2005”. The breakdown of the system, made evident by defaulting, affected promoters then the rest of real estate agents and finally families. The authors of this research point out and advise that "a speculative bubble is based on blind confidence in revaluation" which in this case, led to the contradictory situation of having a large housing stock available and an important number of families who want to purchase a home but are unable to do so due to the high cost of debt. The lesson is 
debería perder en ningún momento su foco principal, es decir, resolver el acceso de las personas a una vivienda digna".

Claudia Paola Espinoza Lizama en Dinámica habitacional en Chillán, Chile (1906-2013) expone los resultados de una investigación sobre la "dinámica habitacional" de esta ciudad en poco más de un siglo. Describe los factores históricos, políticos, económicos, físico natural y demográfico que han incidido en ella y la secuela de poblaciones que se han consolidado como consecuencia. El dato más significativo que da cuenta de este proceso se refiere a la "mancha urbana" que en 1900 ocupaba 379 há. y en 2013 se extiende sobre una superficie de 2.624 há. Aumentando en 113 años 5,9 veces su superficie inicial. La revisión del modo en que los distintos factores van incidiendo en este crecimiento durante el periodo, entrega variada información para reflexionar sobre el mérito de las fuerzas ahí conjugadas.

Jorge Larenas, Antonio Sahady, Marcelo Bravo, Carolina Quilodrán y Xenia Fuster exponen el avance de la investigación sobre Las ruedas de Larmahue: una manifestación de construcción de territorio y paisaje agrario. De todos los artículos de este número, es el que de manera más indirecta trata de la vivienda. La relación, me parece, se sugiere por la modificación e impacto que las "ruedas de agua" ejercen sobre el paisaje y el territorio rural, espacio de la vida campesina y lugar de las viviendas simple: "housing policies should always concentrate on their main purpose, which is to ensure the access to decent housing".

The paper "Housing Dynamics in Chillan, Chile (1906 - 2013)", authored by Claudia Paola Espinoza Lizama, presents the results of research on the "housing dynamics" of this city observed over a period of more than a hundred years. This study describes the historical, political, economic, physical-natural and demographic factors that effected the city and the different populations that have become established as the result of this process. The most significant fact that accounts for this process refers to the "urban sprawl" that covered 379 hectares in 1900 and 2,624 hectares in 2013, an increase in size by 5.9 times over 113 years. The analysis of the way different factors have an effect on the expansion of this city over such a period of time provides diverse information to reflect on the merit of the different forces involved in this process.

Jorge Larenas, Antonio Sahady, Marcelo Bravo, Carolina Quilodran and Xenia Fuster co-authored the paper entitled "The Waterwheels of Larmahue: An Expression of the Construction of Territory and Agricultural Landscape. Of all the papers offered in this issue, this addresses housing in the most indirect way. In my opinion, the relationship is suggested by the modification and impact generated by "waterwheels" on the landscape and the rural territory, the latterbeing the space of rural life and the area that concentrates the 
que ocupan las familias de los hombres de campo. Es evidente, que el trabajo está centrado en estos artilugios que requieren destreza técnica en su construcción y ofrecen una vez erigidos, una singular apariencia en contraste con el paisaje agrario. No se trata efectivamente de un estudio de vivienda agraria o rural, pero no cabe duda que "la necesidad de conseguir un eficiente riego de los campos destinados al cultivo", tuvo un efecto sobre la consolidación de los asentamientos rurales a los que estaba ligada la producción que se pretendía mejorar. Las azudas, ubicadas en la región de O'Higgins, fueron declaradas Monumento Histórico en 1998, pero como suele ocurrir en nuestro país, han tenido nula mantención, lo que indujo a que en 2002 fueran incluidas en la lista de patrimonio mundial en peligro de extinción. Las ruedas de agua han contribuido a la configuración del paisaje cultural agrario de la región, con características únicas en el país.

Loïc Wacquant, Tom Slater y Virgilio Borges Pereira en Estigmatización territorial en acción se refieren a la relación que en la cotidianidad se establece entre los espacios físico, social y simbólico, y que afecta a los habitantes en el "extremo inferior del espectro urbano". El fenómeno de la estigmatización territorial que aborda el artículo vincula el concepto de "identidad deteriorada" de Goffman con el concepto de "poder simbólico" desarrollado por Bourdieu, para establecer "cómo un lugar estigmatizado puede afectar a residentes de barrios houses inhabited by the families of the farm workers. It is clear that the article is focused on those skillfully built devices which, once completed, offer a particular appearance that contrasts with the rural landscape. This is not precisely a study about rural housing; however, there is no doubt that "the need to achieve efficient irrigation of croplands" had an effect on the consolidation of the rural settlements that sought to improve the production of a given product. These waterwheels, located in the O'Higgins Region, were declared a Historical Monument in 1998. However, as is often the case in our country, they have received no maintenance, which has led to their inclusion in the List of World Heritage in Danger in 2002. These devices have contributed to the configuration of the rural cultural landscape of the region, which offers characteristics that cannot be found anywhere else in Chile.

Loïc Wacquant, Tom Slater and Virgilio Borges Pereira, in their research "Territorial Stigmatization in Action", refer to the relationship that is established among the physical, social and symbolic spaces within the context of everyday life and which affect those inhabitants belonging to "the lower-end of the urban spectrum". The phenomenon of territorial stigmatization addressed in this paper relates to the concept of "deteriorated identity", developed by Goffman, and the concept of "symbolic power", proposed by Bourdieu, in order to define "how the blemish of place impacts upon the residents of 
menospreciados". "Este estigma espacial es un fenómeno nuevo y distintivo que se cristalizó a fines del siglo pasado junto con la disolución de los barrios de relegación característicos de la etapa fordista-keynesiana del capitalismo industrial". La indagación de los investigadores apunta a comprender el rol que cumplen las estructuras simbólicas en la producción de desigualdad y marginalidad en la ciudad, y por esa vía sugieren "la necesidad de diseñar políticas públicas enfocadas no solo en la reducción de carencias materiales sino también en la disminución de la presión ejercida por la dominación simbólica de la metrópolis".

El conjunto de los artículos que reúne este número de la revista ofrece un panorama de problemas y desafíos actuales de la vivienda en diversos contextos de desarrollo, cultura y urbanización. Pudiera pensarse que eso los hace divergentes e irreconciliables. Sin embargo, es dramático constatar que todos coinciden (exceptuado el texto de las azudas), desde su diversidad de enfoques, métodos y materia sobre la vivienda, en distintos países y ciudades, en un asunto central ligado a la realidad del sector: la desigualdad, la vulnerabilidad, la exclusión en que se desenvuelve la vida de los habitantes que las ocupan. Asimismo, es notoria la responsabilidad que tiene en los fenómenos estudiados la política pública y el modelo económico en que se desenvuelven las diferentes realidades. Otra singularidad del contenido de los textos es disparaged districts". "This spatial stigma is a new and distinctive phenomenon that emerged at the end of the last century along with the dissolution of the neighborhoods of relegation emblematic of the FordistKeynesian phase of industrial capitalism". The study conducted by these authors aims at understanding the role of symbolic structures in the production of inequality and marginality within the city, thereby suggesting "the need for public policies designed to reduce not only material deprivation, but also in decreasing the pressure for the symbolic domination of the metropolis".

These papers offer an overview of current problems and challenges related to housing within different development, culture and urban contexts. It could be thought that this makes these problems and challenges dissimilar and irreconcilable. However it is disquieting to observe that all the papers (with the exception of the contribution that addresses the waterwheels of Larmahue), share similar outlooks, based on a variety of their approaches, methodologies and topics about housing in different countries and cities. This coincidence gravitates towards a central matter of discussion related to the reality of the sector: inequality, vulnerability and exclusion that govern the lives of the inhabitants living in a given space. The responsibility of public policy and the economic model in which different realities unfold is also noticeable in the phenomenon studied. 
que, siendo todos referidos a la vivienda, ninguno tiene como centro cuestiones de arquitectura, diseño, urbanización o construcción. En cambio, se trata de la vivienda como de un fenómeno socioespacial que afecta a los sectores bajos de la escala socio-económica que puebla las ciudades de hoy, desligado de las características de la obra edificada. ¿No habrá alguna relación entre la configuración espacio-material de la vivienda y las consecuencias socio-espaciales que absorben sus ocupantes? ¿Será posible que la "arquitectura y el urbanismo" de la vivienda contribuyan en hacer más pobres a los pobres, más excluidos a los excluidos, más vulnerables a los vulnerables? De modo tal, ique los medios materiales con que se pretende solucionar las carencias de un grupo social no hacen más que consolidar el estado de pobreza y desigualdad que ya tienen? Visto así, los problemas descritos por los investigadores en sus artículos seguirán repitiéndose, cambiando solo de modo, mientras no acabemos antes con la pobreza.
Another peculiarity found in these papers is that, despite addressing housing issues, none of them is focused on architecture, design, urban development or construction. Rather, housing is addressed as a socio-spatial phenomenon that affects the lower sectors of the socio-economic scale in the cities of today, detached from the characteristics of constructed buildings. Is there any relationship between the spacematerial configuration of housing and the socio-spatial consequences absorbed by its inhabitants? Could it be possible that the architecture and urban development of housing contributes to impoverish those who are already poor, further excluding the excluded and make more vulnerable those who are already vulnerable? In this sense, is it possible that the material resources intended to solve the shortcomings of a social group do no more than consolidate conditions of poverty and inequality? Seen in this light, the problems described by the authors in their respective papers will keep recurring, changing only their ways of operation, meanwhile we do not end poverty. 